\title{
Biomarkers in immune checkpoint inhibition therapy for cancer patients: what is the role of lymphocyte subsets and PD1/ PD-L1?
}

\author{
Puneet Singh ${ }^{1,2,3,4^{*}}$ D. Paul de Souza ${ }^{1,2,3,4}$, Kieran F. Scott ${ }^{1,2,4}$, Bruce M. Hall ${ }^{1,3}$, Nirupama D. Verma ${ }^{1,3}$,
} Therese M. Becker ${ }^{1,3,4}$, James W. T. Toh ${ }^{1,5}$, Mila Sajinovic ${ }^{1,4}$ and Kevin J. Spring 1,2,3,4,6

\begin{abstract}
Although durable clinical responses are achieved in a significant number of patients given Immune checkpoint inhibitors (ICI), like anti-CTLA-4 and anti-PD-1 inhibitors, some of the cancers have shown little or no response to ICI therapy. Even within the known responsive cancers, there is often a subset of non-responsive patients. Due to the accelerated FDA approval of these immunotherapies, the biomarker development has not been able to keep pace. Appropriate predictive, prognostic and surrogate biomarkers are needed to maximally exploit the benefits from ICI therapy for correct and timely stratification of patients to treatment, for monitoring treatment effect, and for avoiding costs and unwanted toxicities when therapy is likely to be ineffective. As the number of clinical trials exploring the utility of these treatments, both as stand-alone and as combination therapy for several cancers is escalating dramatically, the need for appropriate biomarkers is further amplified.

This review discusses the potential biomarkers being investigated in $\mathrm{ICl}$ therapies, focusing mainly on immunohistochemical expression of PDL-1 and the immune correlates. Various immune components discussed here include the cells of innate (natural killer or NK cells) and adaptive (CD4+ and CD8+ cells) immunity, regulatory and inhibitory immune cells (regulatory T cells or Tregs and myeloid derived suppressor cells or MDSCs), as well as cytokines. Immune checkpoint molecule, programmed death receptor ligand-1 (PD-L1) and various molecules and pathways influencing its expression are also discussed.
\end{abstract}

Keywords: CTLA-4, PD-L1, PD-1, Immune checkpoint inhibitor therapies, Immunotherapies, Biomarkers, Neoantigens

\section{Introduction}

Recent advances in immunotherapy have revolutionized the treatment of cancer, adding a fourth pillar to the historic three pillars of surgery, chemotherapy, and radiotherapy. Approval of Interleukin-2 (IL2) for the treatment of metastatic renal cell carcinoma (RCC) in 1992, and for metastatic melanoma (MM) in 1998, by Food and Drug Administration (FDA), were important breakthroughs in immune therapy $[1,2]$, providing the

\footnotetext{
* Correspondence: puneetsingh_bio@y7mail.com

${ }^{1}$ The Ingham Institute for Applied Medical Research, Liverpool, NSW 2170, Australia

${ }^{2}$ School of Medicine, Western Sydney University, Campbelltown, NSW 2560, Australia

Full list of author information is available at the end of the article
}

first 'proof-of-principle' that solely targeting the immune system could lead to durable control of metastatic cancer. The major milestones in the development of immunotherapies are summarized in Fig. 1.

Progress in cancer immunotherapy has been remarkable ever since, especially with the clinical development of Immune checkpoint inhibitors (ICI), like anti-CTLA-4 and anti-PD-1 antibodies inhibitors [3-5]. Durable clinical responses were achieved in a significant number of patients that were given immunotherapies. The cancers with the highest median mutational loads, like melanoma, non-small cell lung cancer (NSCLC), squamous cell cancer of head and neck (SCCHN), bladder cancer and gastric cancers, have demonstrated greater than $15 \%$ response rates to anti-PD-1 or anti-PD-L1 therapy [6-8]. 


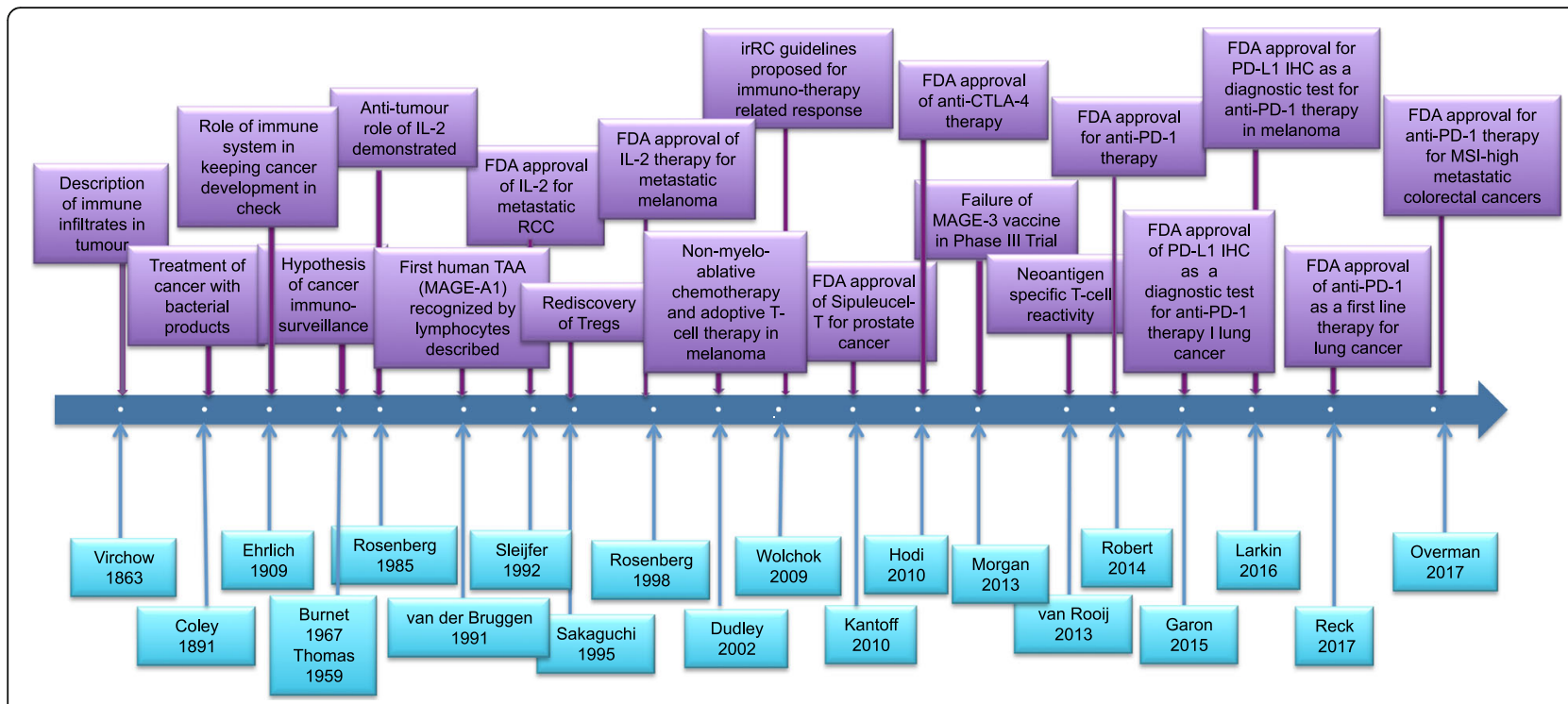

Fig. 1 Timeline figure showing the milestones in the history and development of cancer immunotherapies. FDA (Food and Drug Association); IL-2 (Interleukin 2); PD-1 (Programmed Death receptor-1); PD-L1 (Programmed Death receptor Ligand-1); IHC (Immunohistochemistry). CTLA-4 (Cytotoxic T-lymphocyte associated protein-4); MSI-high (microsatellite instable-high) Additional file 1

Melanoma, a cancer with one of the highest mutational loads among human tumors, showed a particularly high response rate to anti-PD-1 therapy (30-40\%) [9]. ICI therapy has also shown promising results in platinum refractory germ cell testicular cancer. [10]. With such promising results, immunotherapy drugs are positioned to become a backbone therapy for most tumor types. However, cancers with relatively low median mutational loads, such as pancreatic and prostate cancer, have shown little response to PD-1 pathway-blocking antibodies $[7,11]$. In addition, immunotherapy is not without its toxicities, sometimes resulting in patient death [12].

For many years it was known that malignant cells could induce an immune response, which in some cases, destroyed the tumor; however the complexity of the immune system and a lack of technological solutions prevented in-depth study. There are a large number of possible immune responses, but $\mathrm{T}$ cells, especially $\mathrm{CD} 8+\mathrm{T}$ cells, mediate the most critical part of the control of malignant cells. $\mathrm{CD}^{+} \mathrm{T}$ cells are activated by antigen presented by Class I MHC molecules. Mutations in beta 2 microglobulin (B2M), one of the components of Class I MHC molecules have been associated with the response to immunotherapies [13]. CD8 $8^{+}$cells are cytotoxic $\mathrm{T}$ cells, but continued stimulation by antigen renders exhaustion or induces expression of molecules similar to those expressed by $\mathrm{CD} 4{ }^{+} \mathrm{CD} 25^{+}$regulatory $\mathrm{T}$ cells or Treg cells, including cytotoxic T- lymphocyte associated protein-4 (CTLA-4), programmed death receptor-1 (PD-1), programmed death receptor ligand-1 (PD-L1), T-cell immuno-receptor with Immunoglobulin and ITIM domains (TIGIT), lymphocyte activation gene-3 (LAG-3), and T-cell immunoglobulin and mucin domain-3 (TIM-3). The CD8 ${ }^{+}$effector T cells bind to the respective ligands expressed by tumor cells and inhibit the immune response, or causing $\mathrm{T}$ cell death, depending on downstream events. For instance, CTLA- 4 also binds to and blocks CD80 and CD86, preventing further T cell activation through CD28, whereas TIM-3 binds to galectin, resulting in death of the cell expressing TIM-3. The best studied target, the PD-L1 ligand, and its receptor, PD-1, have lead to a rich new generation of therapeutic antibodies recently approved by the FDA, or are under clinical development. However, despite intense efforts, no universal biomarker predicting responses or toxicity has been developed so far. To date, the best-studied biomarkers include tumour mutational load, expression of PD-L1 on tumour cells, or PD-1 receptor on infiltrating lymphocytes.

Current biomarker search is directed at identifying which patients will respond to ICI therapy and which patients will develop side effects. In this review, we discuss immune checkpoint molecule (PD-L1), different molecules/pathways influencing its expression; components of the immune system including cytokines, the cells of innate (natural killer or NK cells) and adaptive immunity (CD4+ and CD8+ cells), regulatory immune cells (Tregs and myeloid derived suppressor cells or MDSCs). Table 1 summarizes the current status of these immune biomarkers in immune checkpoint inhibition therapy.

\section{Immune checkpoint inhibitor therapies}

T-cell recognition of tumor antigens drives the process of elimination of cancer cells via immunological mechanisms. Immune checkpoints minimize collateral tissue 
Table 1 Summary of biomarkers currently under investigation for Immune Checkpoint Inhibition (ICI) therapies

\begin{tabular}{|c|c|c|c|c|}
\hline Biomarker & Type & Pros & Cons & References \\
\hline$\overline{P D-L 1}$ & Predictive Therapeutic & $\begin{array}{l}\text { - First FDA approved } \\
\text { diagnostic for anti-PD1 } \\
\text { therapy in NSCLC an } \\
\text { melanoma } \\
\text { - Direct target of anti- } \\
\text { PD1/PD-L1 therapy }\end{array}$ & $\begin{array}{l}\text { - Does not correlate well } \\
\text { in all the cancer types } \\
\text { - Quite a few technical and } \\
\text { biological variabilities from } \\
\text { cancer to cancer and } \\
\text { patient to patient } \\
\text { - Not 100\% correlation } \\
\text { between its expression } \\
\text { and anti-PD1 treatment } \\
\text { response }\end{array}$ & $\begin{array}{l}\text { Garon, et al. } 2015 \text { [19] } \\
\text { Borghaei, et al. } 2015 \text { [21] } \\
\text { Brahmer, et al. } 2015 \text { [20] } \\
\text { Larkin, et al. 2015a [22] } \\
\text { McDermott, et al. } 2016 \text { [31] }\end{array}$ \\
\hline $\begin{array}{l}\text { Molecules influencing } \\
\text { the expression of PD-L1 }\end{array}$ & Predictive & $\begin{array}{l}\text { - Very standard markers } \\
\text { and therefore easy to } \\
\text { access }\end{array}$ & $\begin{array}{l}\text { - Not too many } \\
\text { - Indirect } \\
\text { - Controversial reports on } \\
\text { their correlation to ICl } \\
\text { therapies }\end{array}$ & $\begin{array}{l}\text { Parsa, et al. } 2007 \text { [34] } \\
\text { Song, et al. } 2013 \text { [35] } \\
\text { Hellmann } 2015 \text { [36] } \\
\text { Larkin, et al. 2015c [38] }\end{array}$ \\
\hline Cytokines & $\begin{array}{l}\text { Predictive } \\
\text { Surrogate }\end{array}$ & $\begin{array}{l}\text { - Gives an idea about the } \\
\text { activation status of other } \\
\text { immune correlates } \\
\text { - Could be used in } \\
\text { conjunction with immune } \\
\text { cell data to give a complete } \\
\text { picture of the immune } \\
\text { system } \\
\text { - Uses less invasive method } \\
\text { since could be assessed } \\
\text { directly in the blood }\end{array}$ & $\begin{array}{l}\text { - Different studies have } \\
\text { reported changes in } \\
\text { different types of cytokines } \\
\text { - Larger studies are needed } \\
\text { - Also need to check the } \\
\text { tumors for the defects in } \\
\text { cytokine signaling }\end{array}$ & $\begin{array}{l}\text { Chang et al., } 2013 \text { [40] } \\
\text { Selby et al., } 2017 \\
\text { Yamazaki et al., } 2017 \text { [43] } \\
\text { Zaretsky et al., } 2016 \text { [45] } \\
\text { Gao et al., } 2016 \text { [46] }\end{array}$ \\
\hline NK cells & $\begin{array}{l}\text { Predictive } \\
\text { Surrogate }\end{array}$ & $\begin{array}{l}\text { - Important as they offer the } \\
\text { first line of defense } \\
\text { - Involved in the production } \\
\text { of important cytokines, } \\
\text { brings about the activation/ } \\
\text { maturation of immune cells }\end{array}$ & $\begin{array}{l}\text { - Controversial data from } \\
\text { different studies on the } \\
\text { changes in the number } \\
\text { of NK subpopulations for } \\
\text { anti-PD-1 treatment } \\
\text { - Larger studies, and } \\
\text { homogenization of the } \\
\text { methods of detection } \\
\text { are needed }\end{array}$ & $\begin{array}{l}\text { Tietze et al., } 2017 \text { [63] } \\
\text { Tallerico et al., } 2015 \text { [64] } \\
\text { Tallerico et al., } 2016 \\
\text { Liu et al., } 2017 \text { [66] }\end{array}$ \\
\hline CD8 $+\mathrm{T}$ cells & $\begin{array}{l}\text { Predictive } \\
\text { Surrogate } \\
\text { Therapeutic }\end{array}$ & $\begin{array}{l}\text { - High pre-treatment } \\
\text { numbers of CD8 }+ \text { T cells } \\
\text { significantly correlate with } \\
\text { better treatment outcomes } \\
\text { for ICI therapies } \\
\text { - Increased numbers are also } \\
\text { predictive of irAE, allowing } \\
\text { for close monitoring of the } \\
\text { patient for early intervention } \\
\text { - Tumor specific CD8 + T cells } \\
\text { have a distinct profile which } \\
\text { may allow for more accurate } \\
\text { monitoring of treatment } \\
\text { response } \\
\text { - Uses less invasive method } \\
\text { since could be assessed } \\
\text { directly in the blood }\end{array}$ & & $\begin{array}{l}\text { Gros, et al. } 2016 \text { [74] } \\
\text { Daud, et al. } 2016 \text { [72] } \\
\text { Ngiow, et al. } 2015 \text { [73] } \\
\text { Larkin, et al. } 2015 b \text { [75] }\end{array}$ \\
\hline CD4 + T cells & $\begin{array}{l}\text { Surrogate } \\
\text { Therapeutic }\end{array}$ & $\begin{array}{l}\text { - One of the very few } \\
\text { markers for anti-CTLA-4 } \\
\text { therapy. } \\
\text { - CD4+ ICOS+ T-cells increases } \\
\text { in a dose-dependent manner, } \\
\text { highlighting their potential as } \\
\text { a surrogate marker for } \\
\text { pharmacodynamic monitoring } \\
\text { of treatment response in } \\
\text { anti-CTLA-4 therapy }\end{array}$ & $\begin{array}{l}\text { - It's role in combating } \\
\text { cancer was recently } \\
\text { unraveled and therefore } \\
\text { it is relatively underexplored }\end{array}$ & $\begin{array}{l}\text { Tran, et al. } 2014 \text { [77] } \\
\text { Ng Tang, et al. } 2013 \text { [79] }\end{array}$ \\
\hline Regulatory T-cells $T_{\text {regs }}$ & $\begin{array}{l}\text { Predictive } \\
\text { Surrogate } \\
\text { Therapeutic }\end{array}$ & $\begin{array}{l}\text { - High pre-treatment } T_{\text {regs }} \\
\text { number in general is } \\
\text { predictive of negative }\end{array}$ & $\begin{array}{l}\text { - A few controversial } \\
\text { reports on the correlation } \\
\text { between } T_{\text {reg }} \text { number and }\end{array}$ & $\begin{array}{l}\text { Hodi, et al. } 2008 \text { [93] } \\
\text { Lowther, et al. } 2016 \text { [92] } \\
\text { Romano, et al. } 2015 \text { [95] }\end{array}$ \\
\hline
\end{tabular}


Table 1 Summary of biomarkers currently under investigation for Immune Checkpoint Inhibition (ICI) therapies (Continued)

\begin{tabular}{|c|c|c|c|c|}
\hline Biomarker & Type & Pros & Cons & References \\
\hline & & $\begin{array}{l}\text { treatment outcome to } \\
\text { ICI therapies } \\
\text { • Being a direct target for } \\
\text { anti-CTLA4 therapy, holds } \\
\text { potential as a surrogate } \\
\text { marker for monitoring } \\
\text { treatment response in } \\
\text { this specific type of ICl } \\
\text { therapy }\end{array}$ & $\begin{array}{l}\text { treatment outcome for } \mathrm{ICl} \\
\text { therapies } \\
\text { - Many studies have } \\
\text { not considered all } \\
\text { the different subtypes } \\
\text { of Tregs }\end{array}$ & Li, et al. 2016 [96] \\
\hline $\begin{array}{l}\text { Myeloid derived } \\
\text { suppressor cells } \\
\text { (MDSCs) }\end{array}$ & $\begin{array}{l}\text { Predictive } \\
\text { Surrogate } \\
\text { Therapeutic }\end{array}$ & $\begin{array}{l}\text { - High pretreatment MDSC } \\
\text { numbers are predictive } \\
\text { of negative ICI treatment } \\
\text { outcome } \\
\text { - Can be utilized as } \\
\text { a marker for } \\
\text { pharmacodynamic } \\
\text { monitoring of treatment } \\
\text { response } \\
\text { - Targeting MDSCs restores } \\
\text { sensitivity to ICI treatments, } \\
\text { and therefore this approach } \\
\text { is being considered for ICI } \\
\text { combination therapies }\end{array}$ & & $\begin{array}{l}\text { Tarhini, et al. } 2014 \text { [100] } \\
\text { Bjoern, et al. } 2016 \text { [101] } \\
\text { Meyer, et al. } 2014 \text { [102] } \\
\text { De Henau, et al. } 2016 \text { [103] }\end{array}$ \\
\hline
\end{tabular}

damage that may result from uncontrolled immune activation under normal circumstances. In cancer cells however, bolstering of these pathways becomes a major mechanism of immune resistance, resulting in blockade of $\mathrm{T}$ effector cell function specific for tumour antigens. As immune checkpoints are initiated by ligand-receptor interactions, aberrant stimulation can be blocked by antibodies or modulated by recombinant forms of ligands or receptors. These blocking molecules form the basis for ICI therapies [14, 15]. Figure $2 \mathrm{a}$ and $\mathrm{b}$ depict the activation of CTLA- 4 and PD-1/PD-L1 axis. The most commonly targeted immune checkpoint molecules are anti-CTLA-4 and anti-PD1 (and anti-PD-L1) antibodies, which bind to their receptors, physically blocking specific ligand interactions, and releasing the T-cells from their immunosuppressive signals (Fig. 2c). Other checkpoint blockade targets include lymphocyte-activation gene 3 (LAG-3), Tumor Necrosis Factor (Ligand) Superfamily, Member 4 (NFRSF4) or OX40 and T-cell immunoglobulin and mucin protein 3 (TIM-3), which are all commonly co-expressed on exhausted PD-1+ T-cells. Targeting of these receptors has demonstrated encouraging results in mouse models, and is also being investigated in clinical trials (NCT02817633) [16-18].

\section{Biomarkers for immune-checkpoint therapy}

Although treatments have focussed on immune checkpoint targets to date, the search for biomarkers have considered a broader view of the cancer-immune system milieu, and many authors believe that it is the interplay between the tumor landscape of individuals and their immune response to it, that determines the response to immune therapies. Here, in addition to discussing the only FDA approved test, immunohistochemistry (IHC) for PD-L1 expression, we discuss the molecules/pathways influencing the expression of PD-L1 entering into a detailed discussion of different components of the immune system that are being explored as potential predictive and/or surrogate biomarkers for ICI therapies.

\section{Immune checkpoint molecules}

Given that immune checkpoint molecules are the direct targets of ICI therapies, it is not surprising their evaluation was the first attempt at defining possible predictive biomarkers; this has been moderately successful, as immunohistochemical expression of PD-L1 was the first FDA approved biomarker for the treatment response to anti-PD-1 therapies. However, the methodologies and appropriate cut-off values of PD-L1 expression are still a matter of debate.

\section{Programmed death receptor ligand - 1 (PD-L1) expression} In October 2015, the FDA approved a PD-L1 immunohistochemistry (IHC) test (PD-L1 IHC 22C3 pharmDx) as a companion diagnostic for pembrolizumab in treating advanced NSCLC [19]. At that time, the PD-L1 IHC 28-8 pharmDx assay was also approved as a complementary, but not required, diagnostic test for nivolumab in lung cancer $[20,21]$. The PD-L1 IHC 28-8 pharmDx assay was subsequently also approved in January 2016 as a complementary test for nivolumab treatment in melanoma [22]. These approvals were based on a number of clinical studies, including a nivolumab study where patients with PD-L1 positive tumors (defined as $>5 \%$ cells 


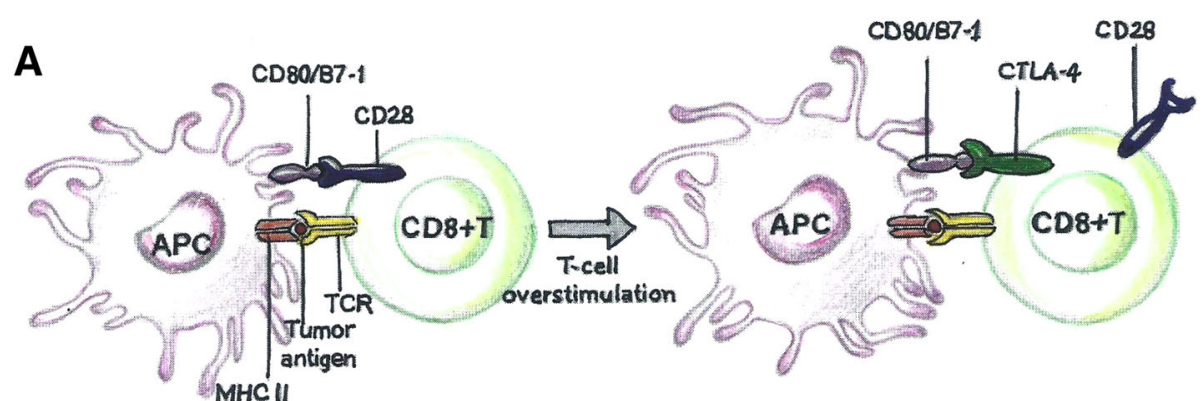

Positive signal

Negative signal

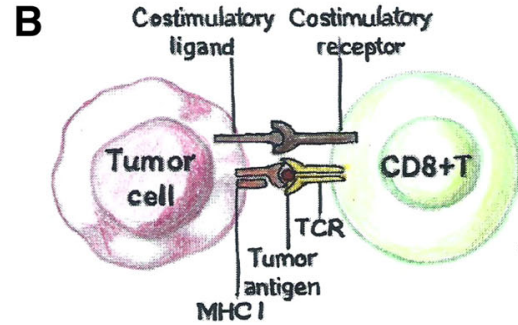

Positive signal

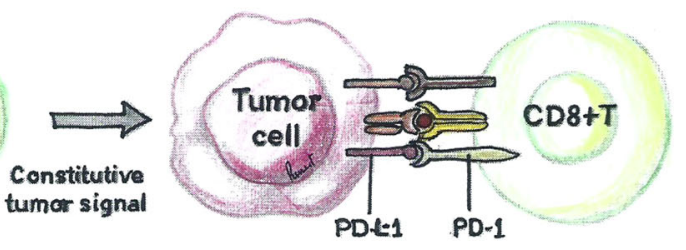

Negative signal

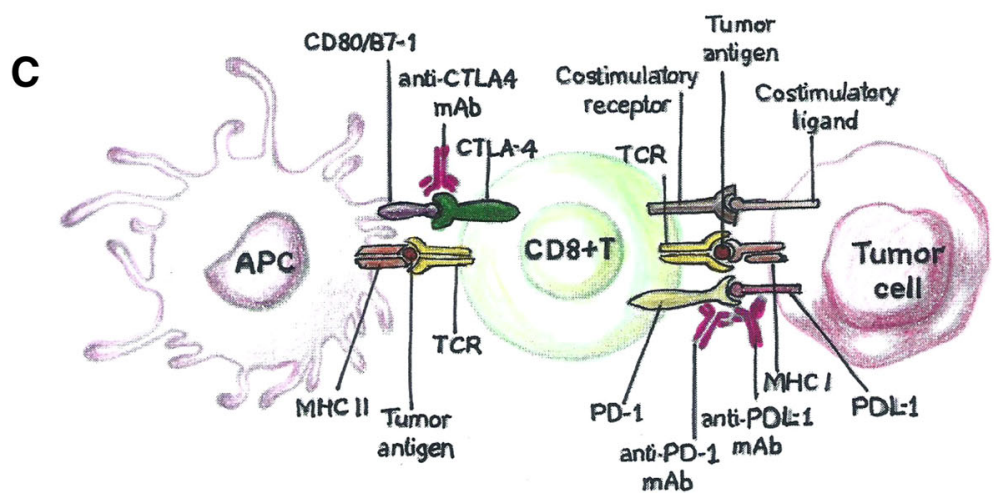

Fig. 2 Immune checkpoint inhibition pathways in tumors (a) Activation of CTLA-4 pathway: Naive and memory T cells express high levels of cell surface CD28 but do not express CTLA-4 on their surface. Instead, CTLA-4 is sequestered in intracellular vesicles. CTLA-4 is a CD28 homologue with higher affinity for the ligands CD80 (B7-1) or CD86 (B7-2) that it shares with CD28. After the T-cell receptor (TCR) is triggered by an antigen encounter, CTLA-4 is transported to the cell surface. The stronger the stimulation through the TCR and CD28, the greater the amount of CTLA-4 that is expressed on the T-cell surface, resulting in a net negative signal transduced by the CTLA-4: CD80/86 interaction. This mechanism results in $C D 8^{+}$T-cell inhibition, despite the presence of widely varying concentrations and affinities of ligand for the TCR. The negative T-cell inhibition or immunosuppressive signal is characterized by decrease in cytokine secretion, $C D 8^{+} \mathrm{T}$-cell inactivation and loss of its cytotoxic function (b) Activation of PD-1/PD L-1 pathway: PD-1, a member of the B7/CD28 family of co-stimulatory receptors, regulates T-cell activation through binding to its ligands, programmed death ligand $1(P D L-1)$ and programmed death ligand 2 (PDL-2). During inflammatory responses in tissues or in the setting of chronic antigen exposure (including tumor antigens), activated T-cells up-regulate PD-1 and continue to express it in tissues. In case of tumors, constitutive tumor signal (tumor antigen and PDL-1 expression) results in overstimulation of CD8 ${ }^{+} T$ cells and inhibits them by inducing a state of anergy or exhaustion. c During Immune Checkpoint Inhibition therapy, anti CTLA-4, anti-PD-L1 or anti-PD-1 antibodies bind to their corresponding target molecules preventing the receptor-ligand interactions of these immune checkpoint inhibitors. This releases $C D 8^{+} T$-cells from immunosuppression imposed on them either by tumor cells via PD-1/PDL-1 pathway or by CTLA-4 pathway, which then resume their anti-oncogenic role

expressing PD-L1), were found twice as likely to respond to treatment as compared to the overall study population $[6,7]$, as well as other studies involving non-small cell lung cancer (NSCLC), melanoma, squamous cell carcinoma of head and neck (SCCHN), renal cell cancer (RCC) and bladder cancer [19-21, 23, 24]. These studies used different PD-L1 IHC assays and different proposed cut-off values for PD-L1 expression, but in general, conclusions suggested that baseline PD-L1 expression in tumor specimens predicted a greater likelihood of response to anti-PD-1 and anti-PD-L1 therapies. 
Nevertheless, it has become apparent that correct assessment of PD-L1 protein expression is impeded by both biological and technical shortcomings. There is wide variability in the expression of PD-L1 across different tumor types, and also within the same tumor type $[8,25-27]$. In a study on a collection of commercially available archival formalin fixed paraffin embedded (FFPE) samples including 30 tumors with multiple samples per case, and 20 pairs of matched primary versus metastatic tissues, discordant results were noted in $6 \%$ of the multi-sampled cases and of $30 \%$ of the matched primary versus metastatic cases. [28]. Further, proprietary IHC tests currently in use or in development use different monoclonal antibodies (mAbs) for PD-L1 detection, and these have been developed in isolation without cross-comparisons. Not all anti-PD-L1 mAbs produce similar staining results as different clones target different epitopes in the PD-L1 protein. The IHC technique itself may have many variables, including antigen retrieval conditions and temperatures, mAb concentrations and incubation times, and detection systems. The conditions under which the specimens are collected and the time of collection with respect to the initiation of treatment might also affect conclusions. Finally, the method of tissue collection also matters; surgical resection compared to needle biopsy could result in a false-negative PD-L1 evaluation [29]. No doubt, PD-L1 IHC as a diagnostic test will continue to evolve as more information regarding clinical correlations from randomized trials becomes available.

With regard to clinical significance, the correlation between PD-L1 expression and long-term outcomes from anti-PD-1 therapy in terms of PFS and OS is yet to be firmly established. Presumably, tumor heterogeneity, as well as differences in population sampling explains why some trials in RCC find a positive correlation of intratumoral PD-L1 expression with response rates and PFS and OS, whereas others do not [30, 31]. Collectively these observations indicate that tumor PD-L1 IHC expression cannot be the sole determinant by which responsiveness to PD-1/PD-L1 targeting is assessed. To overcome some of these issues, PD-L1 expression on circulating tumor cells (CTCs) with respect to ICI therapy is also being evaluated [32,33]. Validation studies of this approach can lead to a non-invasive, liquid biopsy method of accessing PD-L1 expression to monitor disease.

\section{Molecules/pathways influencing the expression of PD-L1} Increased PD-L1 expression by tumor cells in the tumour microenvironment (TME) is generally associated with a better response to anti-PD-1 therapy. In glioblastoma, constitutive oncogenic signalling in tumor cells drives PD-L1 expression. Deletion or silencing of PTEN, resulted in very high expression of PD-L1, implicating the role of PI3K-AKT pathway in PD-L1 upregulation, resulting in immunoresistance in gliomas [34]. PTEN loss has also been associated with upregulation of PD-L1 in colorectal cancers [35]. In lung cancer, the anti-PD-1 response was lower in EGFR - mutant adenocarcinomas and this may be due to increased AKT signalling facilitated by EGFR [36]. Notably, mutant EGFR NSCLC is associated with never-smoker status, which correlates with a considerably lower response rate to anti-PD-1, likely due to lower mutation rates, than smoking-associated lung cancer. The presence of the common oncogenic BRAF-V600E mutation in melanoma did not correlate with PD-L1 expression [37]. In keeping with this, there was no difference in response to anti-PD1 therapy in melanoma in BRAF-V600E mutated versus BRAF wild-type tumors [38].

\section{Components of immune system}

ICI acts by manipulating the immune system, therefore, both cytokines as well as the immune cells hold the potential to be the ultimate predictive as well as surrogate biomarkers for these treatments.

\section{Cytokines}

Cytokines are small non-structural proteins that include interferons, interleukins, the chemokine family, mesenchymal growth factors, the tumor necrosis factor family and adipokines [39]. They are involved in the activation, differentiation, proliferation and chemotaxis of immune cells in immune-related inflammatory response and could be proinflammatory or anti-inflammatory. Their expression profile changes in the presence of tumors. Peripheral blood mononuclear cells (PBMCs) from stage I lung cancer patients were reported to possess distinct cytokine expression patterns compared to both non-cancer patients, and lung cancer patients following tumor removal [40]. Plasma from these patients also showed five altered cytokines (CCL3, IL8, IL1 $\beta$, CXCL10, sIL2R $\alpha$ ). qPCR of PBMCs demonstrated an higher expression of CCL3, IL8 and IL1 $\beta$ in lung cancer patients compared to the same patients at each of four sequential timepoints after removal of their tumors, whereas CXCL10 and IL2R $\alpha$ levels were unchanged. In the same study, similar changes in cytokine and gene expression were observed in in-vitro co-culture systems, when PBMCs from healthy donors were exposed to lung cancer cell line. Certain cytokines, especially interferon (IFN), can be produced by, and act on, both tumor cells and immune cells [41].

The role of cytokines as a biomarker in checkpoint inhibitor therapies is being explored. In vitro studies with combined ipilimumab and nivolumab showed enhanced cytokine secretion in superantigen stimulation of human peripheral blood lymphocytes and in mixed lymphocyte response assays [42]. A single arm, Phase II study (JAPIC-CTI \#11681) evaluating the antitumor activities of nivolumab in advanced melanoma patients conducted 
in Japan found that the pre-treatment serum levels of interferon- $\gamma$, and interleukin- 6 and -10 were significantly higher in the patients with objective tumor responses than in those with tumor progression [43]. In a study presented at the European Lung Cancer Conference (ELCC) 2016, the authors reported the results from two of the Clinical trials, CheckMate $063=$ NCT01721759; CheckMate $017=$ NCT01642004 [44]. In CheckMate 063, patients $(N=117)$ received nivolumab $3 \mathrm{mg} / \mathrm{kg}$ Q2W until progressive disease (PD)/unacceptable toxicity. Checkmate 017 had two arms and the patients were randomized $1: 1$ to receive nivolumab $3 \mathrm{mg} / \mathrm{kg}$ Q2W ( $n=135)$ or docetaxel (doc) $75 \mathrm{mg} / \mathrm{m}^{2} \mathrm{Q} 3 \mathrm{~W}(n=$ 137) until PD or discontinuation due to toxicity/other reasons. They reported that a select group of serum cytokines at baseline may be associated with OS benefit in patients with advanced metastatic squamous NSCLC and suggested that prospective validation of these preliminary findings was needed. Acquired resistance to PD-1 blockade immunotherapy in patients with melanoma was associated with defects in the pathways involved in interferon-receptor signalling in addition to antigen presentation [45]. Similarly, Gao et al. found that the melanoma tumors that were resistant to ipilimumab therapy had defects in IFN- $\gamma$ pathway genes [46]. Further studies in this direction are warranted.

\section{Immune cells}

Cells that potentially predict treatment response include innate immune cells (NK cells), adaptive immune cells $\left(\mathrm{CD}^{+}\right.$and $\left.\mathrm{CD}^{+}\right)$and inhibitory or regulatory immune cells (MDSCs or Tregs). In addition to their role as predictive and surrogate biomarkers in ICI treatment, immune cells were recently implicated in the prediction of immune response adverse events (irAEs) [22]. Changes in total lymphocyte counts, ratios of different cell populations as well as changes in various subpopulations have demonstrated a correlation with ICI treatment response. In addition, monitoring of different $\mathrm{T}$-cell subpopulations like $\mathrm{CD} 4^{+} \mathrm{T}, \mathrm{CD} 8^{+} \mathrm{T}$ cells, NK cells and Tregs, and also analysing the percentage proliferation in each subpopulation using the Ki67 marker, have been proposed as a potential surrogate markers to assess the treatment response for ICI therapies [47-51]. These are considered in more detail below.

\section{Relative counts of immune cell subpopulations}

Lymphocytic profiles have been explored as biomarkers in ICI therapies. On treatment with ipilimumab, metastatic melanoma (MM) patients with absolute lymphocyte counts (ALCs) more than 1000 lymphocytes per cubic millimetres of blood, particularly after the first or second course of ipilimumab (7 weeks), showed significantly improved survival [52]. The baseline expression of immune-related tumor biomarkers and a post-treatment increase (at 3 weeks) in TILs was seen to be significantly associated with ipilimumab clinical activity [53]. In another similar study, in MM patients treated with ipilimumab, patients with baseline neutrophil to lymphocyte ratio (NLR) of $\geq 5$ were associated with significantly increased PFS and OS, compared to those with an NLR $<5[54,55]$. Another study described the cut-off ratio as $\geq 4$ (Zaragoza, et al. 2016). Correlation between absolute eosinophil count (AEC) and response to checkpoint blockade was also demonstrated [56]. An association between absolute lymphocyte count (ALC) and OS in patients with MM treated with ipilimumab was also seen [56]. However, ALC did not significantly correlate with response to either PD-1 inhibitor monotherapy or combination therapy with nivolumab and ipilimumab [57, 58], even though it has been hypothesized that anti-CTLA-4 therapy drives $\mathrm{T}$ cell infiltration into tumors, creating a more optimal environment for anti-PD-1 therapy to work with $[59,60]$.

\section{Natural killer (NK) cells}

NK cells are involved in the innate immunity and are the first line of defense of immune system, guarding against the tumors and fighting the infections. Natural killer T-cells (NKT cells) are CD3+, whereas CD56 ${ }^{\mathrm{dim}}$ NK, CD56 ${ }^{\text {bright }}$ NK are both CD3-. Majority of NK cells in the peripheral blood are CD56 $6^{\mathrm{dim}}$ and are relatively more mature and have higher cytotoxic activity than CD56 ${ }^{\text {bright }}$ cells, which are mainly involved in cytokine secretion [61, 62]. Low baseline levels of NK cells and CD56 ${ }^{\text {dim }}$ NK cells as well as normal levels of CD56 ${ }^{\text {bright }}$ NK cells correlated significantly with a positive response to ipilimumab [63]. High levels of CD56 ${ }^{\text {bright }}$ NK cells predicted a negative outcome. NK cells and CD56 ${ }^{\mathrm{dim}}$ and CD56 ${ }^{\text {bright }}$ NK cell subpopulations in patients with a normal baseline did not change with treatment. NK cells and CD $56^{\mathrm{dim}}$ NK cells showed a significant increase with treatment, whereas CD56 $6^{\text {bright }}$ NK cells were unaffected by treatment. The baseline levels of NK cells also correlated with the number of metastatic organs. In the same study, no such correlation was found in patients treated with pembrolizumab. One previous study also reported the activation and proliferation of CD56 ${ }^{\mathrm{dim}}$ NK cells in response to ipilimumab treatment [64]. Here authors also observed an increase in cytotoxic $\mathrm{CD} 8^{+} \mathrm{T}$ cells, and proposed that ipilimumab treatment induces NK cell maturation, which might in turn drive activation of $\mathrm{CD}^{+} \mathrm{T}$ cells. In melanoma patients being treated with anti-CTLA4 therapy, the survival correlated with low expression of the inhibitory receptor TIM-3 on circulating $\mathrm{T}$ and NK cells at baseline and through the treatment, and with increased frequency of mature circulating CD56 ${ }^{\text {dim }}$ NK cells during treatment [65]. Survival also correlated with low levels of IL-15 in the serum. Authors 
also unravelled the contribution of IL-15 in the expression of PD-1 and TIM-3 on both T-cells and NK cells in in vitro experiments. The increased PD-1 expression on NK cells correlated with poorer survival in oesophageal and liver cancers [66]. In vitro experiments demonstrated that anti-PD-1 antibody markedly enhanced cytokine production and degranulation in NK cells and suppressed apoptosis in them. In addition, anti-PD1 treatment of mouse xenografts showed a significant suppression of growth, which was completely abrogated by NK depletion. NK cells, in addition to being exploited in adoptive NK cell therapy [67], are also emerging as potential biomarkers in ICI therapies and therefore, need to be explored further.

\section{CD4+ and CD8+ T-cells}

CD4+ and CD8+ T cells are cells of adaptive immunity. Similar to chronic infections, $T$ cells in the tumor microenvironment (TME) also exhibit an exhausted phenotype and function. Exhausted $\mathrm{T}$ cells in cancer express high levels of inhibitory receptors, including PD-1, CTLA-4, TIM-3, LAG-3, BTLA and TIGIT, as well as showing impaired effector cytokine production, such as IL-2, TNF- $\alpha$, IFN- $\gamma$ and granzyme B [68]. ICI therapies with anti- CTLA-4 and/or anti- PD-1 monoclonal antibodies can reinvigorate tumor-infiltrating $\mathrm{T}$ lymphocytes resulting in clinical benefits to a large number of patients with advanced cancer. In ICI therapy, CD8+ Cytotoxic T lymphocytes (CTLs) are believed to drive tumor shrinkage, as they can recognize and target cancer cells that present either tumor-specific antigens such as cancer testis antigens or somatic neoantigens [69].

Neoantigen specific T-cells were found to be present in cancers and were amplified as a result of checkpoint blockade therapy [70]. For melanoma, CD8 + T cell density at the invasive tumor edge was correlated with response to anti-PD-1 treatment [71]. Tumeh et al. created a predictive model for the patients treated with pembrolizumab for advanced melanoma. Responding patients had higher pre-treatment numbers of $\mathrm{CD}^{+}, \mathrm{PD}-1$, and PD-L1 expressing cells, both at the tumor margins and in the inside of the tumors. The pre-existing density of $\mathrm{CD} 8^{+} \mathrm{T}$ cells was more closely correlated with response to anti-PD-1 therapy than was PD-L1 expression [71].

In a study on freshly isolated metastatic melanoma samples from 2 cohorts of 20 patients each, the data suggested that the relative abundance of partially exhausted tumorinfiltrating $\mathrm{CD}^{+} \mathrm{T}$ cells predicts response to anti-PD-1 therapy [72]. Even the expression of PD- 1 on $\mathrm{CD}^{+} \mathrm{T}$ cells dictates the response to anti-PD-1. It was shown that PD-1 expression level on $\mathrm{CD}^{+} \mathrm{T}$ cells must be below a certain threshold level to make the tumors sensitive to anti-PD-1 therapy. The same study, using mouse xenograft models, demonstrated that Tregs depletion made tumors more sensitive to anti-PD1 therapy tumors [73]. Another study demonstrated that PD-1 expressing $\mathrm{CD} 8^{+} \mathrm{T}$ cells are neoantigen specific and could be utilized in isolating and expanding this specifically reactive T-cell population [74]. They also demonstrated that the tumor antigen-specificity of PD-1 expressing $\mathrm{T}$ cells in the blood cell compartment very much resembles that of tumor-resident $\mathrm{PD}-1$-expressing $\mathrm{T}$ cells. The PD-1 expressing population of circulating $T$ lymphocytes may provide a valuable window into the tumor-resident antitumor lymphocytes (TILs) by a non-invasive, simplified method. $\mathrm{CD}^{+} \mathrm{T}$-cell clonal expansion could be used as a biomarker that can be used to monitor severe irAEs for early intervention.

Immune checkpoint inhibitors in combination, significantly increase the rate of therapeutic benefit, however, as described previously, the proportion of patients experiencing grade 3-4 irAEs virtually doubles when ipilimumab is combined with nivolumab [75]. In one study the authors found that $\mathrm{CD}^{+} \mathrm{T}$-cell clonal expansion was significantly greater in patients developing grade 2 3 irAEs vs. grade $0-1$ irAEs, and occurred even before the development of the grade 2-3 immune- related toxicities, the median time between the blood draw and the onset of toxicity being 13 days [76]. A few recent studies have detected the presence of neoantigen specific $\mathrm{CD} 4^{+} \mathrm{T}$ amplification as well [77]. ICOS (inducible co-stimulator) is expressed on the cell surface of activated $\mathrm{T}$ cells and plays a role in $\mathrm{T}$ cell expansion and survival. As reviewed by Yuan et al., ICOS expression on $\mathrm{CD}^{+} \mathrm{T}$ cells was shown to increase in a dose-dependent manner in patients with bladder cancer, breast cancer and mesothelioma after treatment with either ipilimumab or tremelimumab [49]. A sustained increase in $\mathrm{CD}_{4}^{+} \mathrm{ICOS}^{+} \mathrm{T}$ cells was observed over 12 weeks after CTLA- 4 blockade therapy and correlated with improved survival in four independent studies [78]. Therefore, $\mathrm{CD}^{+} \mathrm{ICOS}^{+} \mathrm{T}$ cells may have a potential to be reproducible pharmacodynamic biomarker to indicate biological activity for CTLA-4 blockade therapy [79].

\section{Regulatory T-cells (Tregs)}

Under normal physiology, Tregs constrain immune responses and keep other types of $\mathrm{T}$ cells from mounting hyper-aggressive responses. They are recruited to the tumor sites by way of chemokines produced by tumor cells. The induction of forkhead box P3 (FoxP3) expression and conversion of $\mathrm{CD} 4^{+} \mathrm{CD} 25^{-} \mathrm{T}$ cells into Tregs is attributed to the factors produced by TME like hypoxic conditions, STAT3 and HIF-1a [80-83].

Myeloid derived suppressor cells (MDSCs) may also have a role in the induction and/or expansion of Tregs [84]. Tregs contribute to immunosuppression by inhibiting both $\mathrm{CD}^{+}{ }^{+}$and $\mathrm{CD} 8^{+} \mathrm{T}$ cells, NK (natural killer) cells and dendritic cells (DC), using a variety of molecules 
and pathways. Tregs were able to kill $\mathrm{CD}^{+} \mathrm{T}$ cells through granzyme $\mathrm{B}$ and perforin, could impair $\mathrm{CD} 4^{+} \mathrm{T}$ cell responses by pathways involving COX and PGE2, suppressed NK cells via TGF- $\beta$ and DC by way of IL-10 and TGF- $\beta$ [85-88]. In most studies, Treg cells were associated with immunosuppression and worst prognosis. However, some studies showed Tregs to be associated with better prognosis in some cancer types, which seems to be counter intuitive considering the suppressive role of Tregs. Infiltration of CD8 and FOXP3+ Tregs were independently associated with a better outcome in the breast cancer patients treated with neoadjuvant chemotherapy [89]. Improved survival was associated with high-density infiltration of FOXP3+ Tregs in colorectal cancers [90]. One explanation for this positive correlation, suggested by the authors who found that the presence of Tregs in stroma in gastric cancers were associated with improved outcome, was that Tregs most likely inhibit local inflammatory processes that would normally promote tumor carcinogenesis [91]. In addition, the changes in Treg phenotype might also have a bearing on its relationship to the prognosis of the disease. For example, one of the studies showed that dysfunctional, exhausted Tregs that highly express PD- 1 and secrete IFN- $\gamma$ might be a positive indicator of benefit following anti-PD-1 therapies [92].

The decreased numbers of Treg cells in the tumor tissue relative to $\mathrm{CD}^{+} \mathrm{T}$ effector cells, following Ipilimumab treatment have been strongly correlated with clinical benefit from early on $[93,94]$. Patients with glioblastoma multiforme when treated with a PD-1 blocking antibody had a higher proportion of dysfunctional Tregs cells [92]. Melanoma patients treated with ipilimumab demonstrated antibody-dependent cell-mediated cytotoxicity and (ADCC)-mediated Tregs depletion. The prior presence of innate immune cells (macrophages) to mediate ADCC was important for ICI activity [95]. Further, PD-L1 and (forkhead box P3) FOXP3 ${ }^{+}$Tregs may work synergistically or participate in the same molecular pathway and their up-regulated expression may promote immune evasion in breast cancer [96]. These findings provide a theoretical basis for the development of immunotherapies targeting PD-L1 and $\mathrm{FOXP}^{+}$Tregs simultaneously in the treatment of breast cancer, and perhaps other cancers with similar TME.

\section{Myeloid derived suppressor cells (MDSCs)}

Similar to Tregs, tumor resident MDSCs play a suppressive role in tumor biology. Hatziioannou et al. reviewed the cytokines and molecules implicated in the proliferation of MDSCs and their suppressive characteristics, including IL-6, IL-1 $\beta$, TNF- $\alpha$, IL-13/4, and IFN- $\gamma$, STAT3, NF-kB and HIF-1 [97]. One of the most established mechanisms of MDSC suppression is that these molecules secrete the enzyme ARG-1 in the TME, causing uptake of L-arginine by T-cells and subsequent reduction of the production of $\mathrm{CD} 3-\zeta$ chain, in turn resulting in the inhibition of T-cell proliferation [98]. Inhibition of the NK cell response is also mediated by MDSC through the production of TGF- $\beta$, thereby blocking IFN- $\gamma$ production and inhibiting their cytotoxicity. MDSCs produce IL-10, which is one of the components of Type 2 immune response. Type 2 immune response favors tumor growth by promoting angiogenesis as well as by inhibiting cell-mediated immunity and subsequent tumor cell killing [99]. Therefore, through the production of IL-10, MDSCs also skew the phenotype of macrophages toward Type 2 immune responses that favors tumor growth [97]. They may also have a role in the induction and/or expansion of inhibitory Tregs [84].

Many pre-clinical and clinical studies have demonstrated the immunosuppressive role of MDSCs in various different types of cancers. The presence of MDSCs is therefore likely to modulate the effect of ICI therapies. Decrease in circulating MDSCs (myeloid derived suppressor cells) in patients being treated with ipilimumab was associated with improved PFS [100]. A high baseline frequency of MDSCs and high levels of IL-6 was associated with a reduced response to therapy [101]. Similar observations from a study by Meyer et al. suggest that the frequency of monocytic MDSCs may be used as predictive marker of response, as low frequencies identify patients more likely to benefit from ipilimumab treatment [102]. Targeting myeloid cells could possibly overcome resistance to ICI in patients with high levels of suppressive MDSC infiltration in tumours. Efforts have already begun in that direction with selective pharmacologic targeting of the gamma isoform of phosphoinositide 3-kinase (PI3K $\gamma$ ), highly expressed in myeloid cells, that results in restored sensitivity to ICI [103]. This inhibitor is currently being evaluated in a phase 1 clinical trial (NCT02637531).

\section{Discussion}

In 2013, immunotherapy was designated as the 'Breakthrough of the Year' by the Science Magazine [104]. Despite the effectiveness of this treatment in multiple cancer types in the advanced setting, only a relatively small subset of patients responds. Apart from immune-mediated treatment resistance to immune therapies, other mechanisms can either potentially enhance or contribute to treatment resistance. For instance, chemotherapeutic agents such as anthracyclines and oxaliplatin may eventually lead to secondary expansion of immunosuppressant cells in the host, exhaustion of immune effectors and the emergence of chemo-resistant tumor clones [105]. Timing of immune therapies may also play a role in improving outcomes. Earlier treatment in the disease course is an obvious possibility; the incidence of distant metastases after surgical 
intervention may be reduced [106]. Combining immunotherapies with first line therapies may also result in better treatment outcomes [107]. For example, radiotherapy is believed to increase the efficacy of ICI by triggering the release of TAAs and /or damage-associated molecular pattern molecules (DAMPs), both of which may activate the innate and adaptive immune system, and enhance tumour-cell immunogenicity $[105,108,109]$. On the other hand, radiotherapy tends to induce clonal diversity in tumors through the induction of further mutations, which may lead to eventual resistance to immune therapies.

\section{Conclusion}

Prognostic and surrogate biomarkers are actively being investigated to maximally utilize the potential of ICI therapies. Given the modest success of potential biomarkers to date, it is unlikely that a single biomarker will suffice, but a better understanding of the interplay of multiple factors in an individual may lead to predictive profiles. Thus the genetic and immune profile of the cancer, or the 'cancer-immune setpoint', of an individual may help to predict treatment response for immunotherapies [110]. As discussed, PD-L1 expression by tumors, although FDA approved, is modestly effective, at best, for prediction of treatment response. The field is still evolving, however, and at present, it appears that a combination of absolute pre-treatment lymphocyte counts, ratios of different immune cell populations (e.g. Teff/ Treg), or proportions of NK cells, $\mathrm{CD}_{4}^{+} \mathrm{T}$ and $\mathrm{CD}^{+} \mathrm{T}$ cells, Tregs, and MDSCs are the leading candidates. The products of these active immune cells may also be helpful in predicting treatment response, such as cytokine expression profiles [40]. These studies highlight the cross talk between the highly individualized tumor-immune landscapes of patients. Therefore, it makes sense that a multi-factorial, highly individualized biomarker profile for the most efficient delivery of ICI treatment is required.

\section{Future directions}

Based on the evidence from the studies discussed here and several other similar studies, it is clear that immunotherapy needs to be considered as a first or early line therapy, before the chemo- or radio- therapeutic agents would induce further mutations resulting in tumor heterogeneity, clonal diversity and in turn the resistant tumor clones. To make this possible, it is imperative that the ICI treatment responsive patients be identified and distinguished from non-responsive patients. For appropriate delivery of immunotherapies, use of these multiple biomarkers discussed here, combined with genetic profiling, would be very practical approach. This multifactorial biomarker approach may help screen as well as monitor the patients; better inform the design and help adjust the treatment regimes; save the crucial time and exorbitant treatment costs by distinguishing responders from the non-responders in a timely manner; and facilitate the extension of ICI treatment to non-responders within the commonly treated immunogenic cancers as well as to other poorly immunogenic cancers currently non-responsive to ICI Additional file 1.

\section{Additional file}

Additional file 1: Refers to References for Figure 1 (in chronological order). (DOCX $130 \mathrm{~kb}$ )

\section{Abbreviations}

ADCC: antibody-dependent cell-mediated cytotoxicity; AEC: absolute eosinophil count; ALCs: absolute lymphocyte count; ARG-1: arginase-1; B2M: beta 2 microglobulin; BRAF: B-Raf proto-oncogene; BRAF-V600E: B-Raf proto-oncogene, valine to glutamic acid mutation; BTLA: B and T lymphocyte associated; CCL3: C-C motif chemokine ligand 3; CD28: cluster of differentiation28 positive cells; CD3- 乙: CD3 antigen, epsilon polypeptide; CD4+ cells: cluster of differentiation-4 positive cells; $C D 4^{+} \mathrm{CD} 25^{+}$: cluster of differentiation-4 positive cells and cluster of differentiation-25 positive cells; CD56 ${ }^{\text {bright }} \mathrm{NK}$ : cluster of differentiation-56 bright, natural killer; CD56 ${ }^{\text {dim }}$ NK: cluster of differentiation-56 dim, natural killer; CD8+ cells: cluster of differentiation-8 positive cells; CD80: cluster of differentiation-80 dim, natural killer; CD86: cluster of differentiation-86 dim, natural killer; COX: cyclooxygenase; CTCs: circulating tumor cells; CTLA-4: cytotoxic T-lymphocyte associated protein-4;

CTLS: cytotoxic T-lymphocytes; CXCL10: C-X-C motif chemokine ligand 10; DAMPs: damage-associated molecular pattern molecules; DC: dendritic cells; EGFR: epidermal growth factor receptor; ELCC: European Lung Cancer Conference; FDA: Food and Drug Administration; FFPE: formalin fixed paraffin embedded; FoxP3: forkhead box P3; HIF-1: hypoxia inducible factor- 1; HIF-1a: hypoxia inducible factor- 1a; ICl: immune checkpoint therapy; ICOS: inducible co-stimulator; IFN: interferon; IFN- $\gamma$ : interferon gamma; IHC: immuno histochemistry; IL-10: interleukin 10; IL-13/4: interleukin 13/4; IL-15: interleukin 15; IL1ß: interleukin 1 beta; IL2: interleukin 2; IL2Ra: interleukin 6 R alpha; IL-6: interleukin 6; IL8: interleukin 8; irAEs: immune related adverse events; ITIM: immunoreceptor tyrosine-based inhibitory motif; JAPIC-CTI: Japan Pharmaceutical Information Centre- Clinical Trials Information; Ki67: name derived from the city of origin, 'Kiel', Germany; LAG-3: Iymphocyte activation gene-3; mAbs: mono-clonal antibodies; MDSCs: Myeloid derived suppressor cells; MHC: major histocompatibility complex; MM: metastatic melanoma; NF-kB: nuclear factor - kappa B; NFRSF4: Tumor Necrosis Factor (Ligand) Superfamily, Member 4; NK cells: natural killer cells; NLR: neutrophil to leucocyte ratio; NSCLC: non-small cell lung cancer; OS: overall survival; OX40: TNF receptor superfamily member 4; PBMCs: peripheral blood mononuclear cells; PD: progressive disease; PD-1: programmed death receptor- 1; PD-L1: programmed death receptor ligand-1; PFS: progression free survival; PGE2: prostaglandin E synthase 2; PI3K-AKT: phosphoinositide-3-kinase- serine -threonine kinase; PI3KY: phosphoinositide-3-kinase gamma; PTEN: phosphatase and tensin homologue; qPCR: quantitative polymerase chain reaction; RCC: renal cell carcinoma; SCCHN: squamous cell cancer of head and neck; slL2Ra: soluble interleukin 2 receptor alpha; STAT3: signal transducer and activator of transcription; T cells: thymus lymphocyte cells; Teff/Treg: effector T cells / regulatory T cells; TGF- $\beta$ : transforming growth factor- beta; TIGIT: T-cell immuno-receptor with Immunoglobulin and ITIM domains; TILs: tumor infiltrating lymphocytes; TIM-3: T-cell immunoglobulin and mucin domain-3; TME: tumor microenvironment; TNF-a: tumor necrosis factor - alpha; Tregs: regulatory $T$ cells

\section{Acknowledgements}

Not applicable.

Funding

No specific funding was received to support the preparation and writing of this review.

\section{Availability of data and materials}

"All data generated or analysed during this study are included in this published article [and its supplementary information files]. 


\section{Authors' contributions}

PS conceived of the review, collated the data, wrote and edited the review. $\mathrm{PdS}$ co-conceived the review and completed major edits. KFS and BH collected data from online databases and edited the review. NV, TB, JT and KJS discussed and edited the review. MS proofread the review. All authors read and approved the final manuscript.

\section{Ethics approval and consent to participate}

Not applicable.

\section{Consent for publication}

Not applicable.

\section{Competing interests}

The authors declare that they have no competing interests.

\section{Publisher's Note}

Springer Nature remains neutral with regard to jurisdictional claims in published maps and institutional affiliations.

\section{Author details}

${ }^{1}$ The Ingham Institute for Applied Medical Research, Liverpool, NSW 2170, Australia. ${ }^{2}$ School of Medicine, Western Sydney University, Campbelltown, NSW 2560, Australia. ${ }^{3}$ Southwest Sydney Clinical School, University of New South Wales, Liverpool, NSW 2170, Australia. ${ }^{4}$ Centre for Oncology Education, Research and Translation, Liverpool, NSW 2170, Australia. ${ }^{5}$ Department of Colorectal Surgery, Westmead Hospital, Westmead, NSW 2145, Australia. ${ }^{6}$ Medical Oncology, Liverpool Hospital, Liverpool, NSW 2170, Australia.

Received: 7 November 2018 Accepted: 20 January 2019 Published online: 07 February 2019

\section{References}

1. Rosenberg SA, Lotze MT, Muul LM, Leitman S, Chang AE, Ettinghausen SE, Matory YL, Skibber JM, Shiloni E, Vetto JT, et al. Observations on the systemic administration of autologous lymphokine-activated killer cells and recombinant interleukin-2 to patients with metastatic cancer. N Engl J Med. 1985;313(23):1485-92.

2. Rosenberg SA, Yang JC, White DE, Steinberg SM. Durability of complete responses in patients with metastatic cancer treated with high-dose interleukin-2: identification of the antigens mediating response. Ann Surg. 1998;228(3):307-19.

3. Hodi FS, O'Day SJ, McDermott DF, Weber RW, Sosman JA, Haanen JB, Gonzalez R, Robert C, Schadendorf D, Hassel JC, et al. Improved survival with ipilimumab in patients with metastatic melanoma. N Engl J Med. 2010; 363(8):711-23.

4. Robert C, Ribas A, Wolchok JD, Hodi FS, Hamid O, Kefford R, Weber JS, Joshua AM, Hwu WJ, Gangadhar TC, et al. Anti-programmed-deathreceptor-1 treatment with pembrolizumab in ipilimumab-refractory advanced melanoma: a randomised dose-comparison cohort of a phase 1 trial. Lancet (London, England). 2014;384(9948):1109-17.

5. Robert C, Long GV, Brady B, Dutriaux C, Maio M, Mortier L, Hassel JC, Rutkowski P, McNeil C, Kalinka-Warzocha E, et al. Nivolumab in previously untreated melanoma without BRAF mutation. N Engl J Med. 2015;372(4):320-30.

6. Brahmer JR, Drake CG, Wollner I, Powderly JD, Picus J, Sharfman WH, Stankevich E, Pons A, Salay TM, McMiller TL, et al. Phase I study of singleagent anti-programmed death-1 (MDX-1106) in refractory solid tumors: safety, clinical activity, pharmacodynamics, and immunologic correlates. J Clin Oncol. 2010;28(19):3167-75.

7. Topalian SL, Hodi FS, Brahmer JR, Gettinger SN, Smith DC, McDermott DF, Powderly JD, Carvajal RD, Sosman JA, Atkins MB, et al. Safety, activity, and immune correlates of anti-PD-1 antibody in cancer. N Engl J Med. 2012; 366(26):2443-54

8. Herbst RS, Soria JC, Kowanetz M, Fine GD, Hamid O, Gordon MS, Sosman JA, McDermott DF, Powderly JD, Gettinger SN, et al. Predictive correlates of response to the anti-PD-L1 antibody MPDL3280A in cancer patients. Nature. 2014;515(7528):563-7.

9. Topalian SL, Taube JM, Anders RA, Pardoll DM. Mechanism-driven biomarkers to guide immune checkpoint blockade in cancer therapy. Nat Rev Cancer. 2016;16(5):275-87.
10. Semaan A, Haddad FG, Eid R, Kourie HR, Nemr E. Immunotherapy: last bullet in platinum refractory germ cell testicular cancer. Future Oncol. 2019. https://doi.org/10.2217/fon-2018-0571.

11. Brahmer JR, Tykodi SS, Chow LQ, Hwu WJ, Topalian SL, Hwu P, Drake CG, Camacho LH, Kauh J, Odunsi K, et al. Safety and activity of anti-PD-L1 antibody in patients with advanced cancer. N Engl J Med. 2012;366(26):2455-65.

12. Le DT UJN, Wang H, Bartlett BR, Kemberling $H$, Eyring AD, Skora AD, Luber BS, Azad NS, Laheru D, et al. PD-1 Blockade in Tumors with Mismatch-Repair Deficiency. N Engl J Med. 2015;372(26):2509-20,

13. Sade-Feldman M, Jiao YJ, Chen JH, Rooney MS, Barzily-Rokni M, Eliane JP, Bjorgaard SL, Hammond MR, Vitzthum H, Blackmon SM, et al. Resistance to checkpoint blockade therapy through inactivation of antigen presentation. Nat Commun. 2017:8(1):1136

14. Pardoll DM. The blockade of immune checkpoints in cancer immunotherapy. Nat Rev Cancer. 2012;12(4):252-64.

15. Walker $L S$, Sansom DM. The emerging role of CTLA4 as a cell-extrinsic regulator of T cell responses. Nat Rev Immunol. 2011;11(12):852-63.

16. Ngiow SF, von Scheidt B, Akiba H, Yagita H, Teng MW, Smyth MJ. Anti-TIM3 antibody promotes $\mathrm{T}$ cell IFN-gamma-mediated antitumor immunity and suppresses established tumors. Cancer Res. 2011;71(10):3540-51.

17. Sakuishi K, Apetoh L, Sullivan JM, Blazar BR, Kuchroo VK, Anderson AC Targeting Tim-3 and PD-1 pathways to reverse T cell exhaustion and restore anti-tumor immunity. J Exp Med. 2010;207(10):2187-94.

18. Woo SR, Turnis ME, Goldberg MV, Bankoti J, Selby M, Nirschl CJ, Bettini ML, Gravano DM, Vogel P, Liu CL, et al. Immune inhibitory molecules LAG-3 and PD-1 synergistically regulate T-cell function to promote tumoral immune escape. Cancer Res. 2012;72(4):917-27.

19. Garon EB, Rizvi NA, Hui R, Leighl N, Balmanoukian AS, Eder JP, Patnaik A, Aggarwal C, Gubens M, Horn L, et al. Pembrolizumab for the treatment of non-small-cell lung cancer. N Engl J Med. 2015;372(21):2018-28.

20. Brahmer J, Reckamp KL, Baas P, Crino L, Eberhardt WE, Poddubskaya E, Antonia S, Pluzanski A, Vokes EE, Holgado E, et al. Nivolumab versus docetaxel in advanced squamous-cell non-small-cell lung cancer. N Engl J Med. 2015;373(2):123-35.

21. Borghaei H, Paz-Ares L, Horn L, Spigel DR, Steins M, Ready NE, Chow LQ, Vokes EE, Felip E, Holgado E, et al. Nivolumab versus docetaxel in advanced nonsquamous non-small-cell lung cancer. N Engl J Med. 2015;373(17):1627-39.

22. Larkin J, Chiarion-Sileni V, Gonzalez R, Grob JJ, Cowey CL, Lao CD, Schadendorf D, Dummer R, Smylie M, Rutkowski P, et al. Combined Nivolumab and Ipilimumab or monotherapy in untreated melanoma. N Engl J Med. 2015;373(1):23-34.

23. Lipson EJ, Forde PM, Hammers HJ, Emens LA, Taube JM, Topalian SL. Antagonists of PD-1 and PD-L1 in Cancer treatment. Semin Oncol. 2015; 42(4):587-600

24. Sunshine J, Taube JM. PD-1/PD-L1 inhibitors. Curr Opin Pharmacol. 2015;23: 32-8.

25. Powles $T$, Eder JP, Fine GD, Braiteh FS, Loriot $Y$, Cruz C, Bellmunt J, Burris HA, Petrylak DP, Teng SL, et al. MPDL3280A (anti-PD-L1) treatment leads to clinical activity in metastatic bladder cancer. Nature. 2014;515(7528):558-62.

26. Chen BJ, Chapuy B, Ouyang J, Sun HH, Roemer MG, Xu ML, Yu H, Fletcher CD, Freeman GJ, Shipp MA, et al. PD-L1 expression is characteristic of a subset of aggressive B-cell lymphomas and virus-associated malignancies. Clin Cancer Res. 2013;19(13):3462-73.

27. D'Angelo SP, Shoushtari AN, Agaram NP, Kuk D, Qin LX, Carvajal RD, Dickson MA, Gounder M, Keohan ML, Schwartz GK, et al. Prevalence of tumor-infiltrating lymphocytes and PD-L1 expression in the soft tissue sarcoma microenvironment. Hum Pathol. 2015;46(3):357-65.

28. Phillips T, Simmons P, Inzunza HD, Cogswell J, Novotny J Jr, Taylor C, Zhang $X$. Development of an automated PD-L1 immunohistochemistry (IHC) assay for non-small cell lung cancer. Appl Immunohistochem Mol Morphol. 2015; 23(8):541-9.

29. Kitazono S, Fujiwara Y, Tsuta K, Utsumi H, Kanda S, Horinouchi H, Nokihara H, Yamamoto N, Sasada S, Watanabe S, et al. Reliability of small biopsy samples compared with resected specimens for the determination of programmed death-ligand 1 expression in non--small-cell lung Cancer. Clin Lung Cancer. 2015;16(5):385-90.

30. Motzer RJ, Rini Bl, McDermott DF, Redman BG, Kuzel TM, Harrison MR, Vaishampayan UN, Drabkin HA, George S, Logan TF, et al. Nivolumab for metastatic renal cell carcinoma: results of a randomized phase II trial. J Clin Oncol. 2015;33(13):1430-7. 
31. McDermott DF, Sosman JA, Sznol M, Massard C, Gordon MS, Hamid O, Powderly JD, Infante JR, Fasso M, Wang $\mathrm{W}$, et al. Atezolizumab, an antiprogrammed death-ligand 1 antibody, in metastatic renal cell carcinoma: Long-term safety, clinical activity, and immune correlates from a phase la study. J Clin Oncol. 2016;34(8):833-42.

32. Nicolazzo C, Raimondi C, Mancini M, Caponnetto S, Gradilone A, Gandini O, Mastromartino M, Del Bene G, Prete A, Longo F, et al. Monitoring PD-L1 positive circulating tumor cells in non-small cell lung cancer patients treated with the PD-1 inhibitor Nivolumab. Sci Rep. 2016;6:31726.

33. Satelli A, Batth IS, Brownlee Z, Rojas C, Meng QH, Kopetz S, Li S. Potential role of nuclear PD-L1 expression in cell-surface vimentin positive circulating tumor cells as a prognostic marker in cancer patients. Sci Rep. 2016;6:28910.

34. Parsa AT, Waldron JS, Panner A, Crane CA, Parney IF, Barry JJ, Cachola KE, Murray JC, Tihan T, Jensen MC, et al. Loss of tumor suppressor PTEN function increases B7-H1 expression and immunoresistance in glioma. Nat Med. 2007;13(1):84-8.

35. Song $M$, Chen D, Lu B, Wang C, Zhang J, Huang L, Wang X, Timmons CL, $\mathrm{Hu}$ J, Liu B, et al. PTEN loss increases PD-L1 protein expression and affects the correlation between PD-L1 expression and clinical parameters in colorectal cancer. PLoS One. 2013;8(6):e65821.

36. Hellmann MD. Efficacy of pembrolizumab in key subgroups of patients with advanced NSCLC. J Thor Oncol. 2015;10(suppl. 2) (Abstract MINI03.05).

37. Rodic N, Anders RA, Eshleman JR, Lin MT, Xu H, Kim JH, Beierl K, Chen S, Luber BS, Wang $H$, et al. PD-L1 expression in melanocytic lesions does not correlate with the BRAF V600E mutation. Cancer Immunol Res. 2015;3(2): 110-5.

38. Larkin J, Lao CD, Urba WJ, McDermott DF, Horak C, Jiang J, Wolchok JD. Efficacy and safety of Nivolumab in patients with BRAF V600 mutant and BRAF wild-type advanced melanoma: a pooled analysis of 4 clinical trials. JAMA Oncol. 2015;1(4):433-40.

39. Dinarello CA. Historical insights into cytokines. Eur J Immunol. 2007; 37(Suppl 1):S34-45.

40. Chang DH, Rutledge JR, Patel AA, Heerdt BG, Augenlicht LH, Korst RJ. The effect of lung cancer on cytokine expression in peripheral blood mononuclear cells. PLoS One. 2013;8(6):e64456.

41. Parker BS, Rautela J, Hertzog PJ. Antitumour actions of interferons: implications for cancer therapy. Nat Rev Cancer. 2016;16(3):131-44.

42. Selby MJ, Engelhardt JJ, Johnston RJ, Lu LS, Han M, Thudium K, Yao D, Quigley M, Valle J, Wang C, et al. Correction: preclinical development of Ipilimumab and Nivolumab combination immunotherapy: mouse tumor models, in vitro functional studies, and cynomolgus macaque toxicology. PLoS One. 2016;11(11):e0167251.

43. Yamazaki N, Kiyohara Y, Uhara H, lizuka H, Uehara J, Otsuka F, Fujisawa Y, Takenouchi T, Isei T, Iwatsuki K, et al. Cytokine biomarkers to predict antitumor responses to nivolumab suggested in a phase 2 study for advanced melanoma. Cancer Sci. 2017;108(5):1022-31.

44. Lena H, Rizvi NA, Wolf J, Cappuzzo F, Zalcman G, Baas P, Mazieres J, Farsaci B, Blackwood-Chirchir MA, Ramalingam S. 1370: Nivolumab in patients (pts) with advanced refractory squamous (SQ) non-small cell lung cancer (NSCLC): 2-year follow-up from CheckMate 063 and exploratory cytokine profling analyses. J Thorac Oncol. 2016;11(4):S115-6.

45. Zaretsky JM, Garcia-Diaz A, Shin DS, Escuin-Ordinas H, Hugo W, HuLieskovan S, Torrejon DY, Abril-Rodriguez G, Sandoval S, Barthly L, et al. Mutations associated with acquired resistance to PD-1 blockade in melanoma. N Engl J Med. 2016;375(9):819-29.

46. Gao J, Shi LZ, Zhao H, Chen J, Xiong L, He Q, Chen T, Roszik J, Bernatchez C, Woodman SE, et al. Loss of IFN-gamma Pathway Genes in Tumor Cells as a Mechanism of Resistance to Anti-CTLA-4 Therapy. Cell. 2016;167(2):397-404.e399.

47. Simeone E, Gentilcore G, Giannarelli D, Grimaldi AM, Caraco C, Curvietto M, Esposito A, Paone M, Palla M, Cavalcanti E, et al. Immunological and biological changes during ipilimumab treatment and their potential correlation with clinical response and survival in patients with advanced melanoma. Cancer Immunol Immunother. 2014;63(7):675-83.

48. Weber JS, Hamid O, Chasalow SD, Wu DY, Parker SM, Galbraith S, Gnjatic S, Berman D. Ipilimumab increases activated $T$ cells and enhances humoral immunity in patients with advanced melanoma. J Immunother (Hagerstown, Md : 1997). 2012;35(1):89-97.

49. Yuan J, Hegde PS, Clynes R, Foukas PG, Harari A, Kleen TO, Kvistborg P, Maccalli C, Maecker HT, Page DB, et al. Novel technologies and emerging biomarkers for personalized cancer immunotherapy. J Immunother Cancer. 2016:4:3.
50. Curti BD, Kovacsovics-Bankowski M, Morris N, Walker E, Chisholm L, Floyd K, Walker J, Gonzalez I, Meeuwsen T, Fox BA, et al. OX40 is a potent immunestimulating target in late-stage cancer patients. Cancer Res. 2013;73(24): 7189-98.

51. Sun Y, Yang K, Bridal T, Ehrhardt AG. Robust Ki67 detection in human blood by flow cytometry for clinical studies. Bioanalysis. 2016;8(23):2399-413.

52. Ku GY, Yuan J, Page DB, Schroeder SE, Panageas KS, Carvajal RD, Chapman PB, Schwartz GK, Allison JP, Wolchok JD. Single-institution experience with ipilimumab in advanced melanoma patients in the compassionate use setting: lymphocyte count after 2 doses correlates with survival. Cancer. 2010;116(7):1767-75.

53. Hamid O, Schmidt H, Nissan A, Ridolfi L, Aamdal S, Hansson J, Guida M, Hyams DM, Gomez H, Bastholt L, et al. A prospective phase II trial exploring the association between tumor microenvironment biomarkers and clinical activity of ipilimumab in advanced melanoma. J Transl Med. 2011;9:204.

54. Zaragoza J, Caille A, Beneton N, Bens G, Christiann F, Maillard H, Machet L. High neutrophil to lymphocyte ratio measured before starting ipilimumab treatment is associated with reduced overall survival in patients with melanoma. Br J Dermatol. 2016;174(1):146-51.

55. Ferrucci PF, Gandini S, Battaglia A, Alfieri S, Di Giacomo AM, Giannarelli D, Cappellini GC, De Galitiis F, Marchetti P, Amato G, et al. Baseline neutrophilto-lymphocyte ratio is associated with outcome of ipilimumab-treated metastatic melanoma patients. Br J Cancer. 2015;112(12):1904-10.

56. Delyon J, Mateus C, Lefeuvre D, Lanoy E, Zitvogel L, Chaput N, Roy S, Eggermont AM, Routier E, Robert C. Experience in daily practice with ipilimumab for the treatment of patients with metastatic melanoma: an early increase in lymphocyte and eosinophil counts is associated with improved survival. Ann Oncol. 2013;24(6):1697-703.

57. Postow MA, Callahan MK, Barker CA, Yamada Y, Yuan J, Kitano S, Mu Z, Rasalan T, Adamow M, Ritter E, et al. Immunologic correlates of the abscopal effect in a patient with melanoma. N Engl J Med. 2012;366(10): 925-31.

58. Johnson DB, Peng C, Sosman JA. Nivolumab in melanoma: latest evidence and clinical potential. Ther Adv Med Oncol. 2015;7(2):97-106.

59. Postow MA, Callahan MK, Wolchok JD. Immune checkpoint blockade in Cancer therapy. J Clin Oncol. 2015;33(17):1974-82.

60. Hurwitz A, Lee S, Knox S, Kohrt HE. 29(th) Annual meeting of the Society for Immunotherapy of Cancer (SITC). J Immunother Cancer. 2015:3(17).

61. Mandal A, Viswanathan C. Natural killer cells: in health and disease. Hematol Oncol Stem Cell Ther. 2015;8(2):47-55.

62. Caligiuri MA. Human natural killer cells. Blood. 2008;112(3):461-9.

63. Tietze JK, Angelova D, Heppt MV, Ruzicka T, Berking C. Low baseline levels of NK cells may predict a positive response to ipilimumab in melanoma therapy. Exp Dermatol. 2017;26(7):622-9.

64. Tallerico R, Cristiani CM, Capone M, Madonna G, Mallardo D, Simeone E, Dominijanni A, Grimaldi AM, Colucci F, Ascierto PA, et al. Analysis of T and NK cells immune response in Ipilimumab treated melanoma patients. J Transl Med. 2015;13(Suppl 1):08.

65. Tallerico R, Cristiani CM, Staaf E, Garofalo C, Sottile R, Capone M, Pico de Coana Y, Madonna G, Palella E, Wolodarski M, et al. IL-15, TIM-3 and NK cells subsets predict responsiveness to anti-CTLA-4 treatment in melanoma patients. Oncoimmunology. 2017;6(2):e1261242.

66. Liu Y, Cheng Y, Xu Y, Wang Z, Du X, Li C, Peng J, Gao L, Liang X, Ma C. Increased expression of programmed cell death protein 1 on NK cells inhibits NK-cell-mediated anti-tumor function and indicates poor prognosis in digestive cancers. Oncogene. 2017;36(44):6143-53.

67. Guo Y, Feng X, Jiang Y, Shi X, Xing X, Liu X, Li N, Fadeel B, Zheng C. PD1 blockade enhances cytotoxicity of in vitro expanded natural killer cells towards myeloma cells. Oncotarget. 2016;7(30):48360-74.

68. Jiang Y, Li Y, Zhu B. T-cell exhaustion in the tumor microenvironment. Cell Death Dis. 2015;6:e1792.

69. Restifo NP, Dudley ME, Rosenberg SA. Adoptive immunotherapy for cancer: harnessing the T cell response. Nat Rev Immunol. 2012;12(4):269-81.

70. Lundegaard C, Lamberth K, Harndahl M, Buus S, Lund O, Nielsen M. NetMHC-3.0: accurate web accessible predictions of human, mouse and monkey MHC class I affinities for peptides of length 8-11. Nucleic Acids Res. 2008;36(Web Server issue):W509-12.

71. Tumeh PC, Harview CL, Yearley JH, Shintaku IP, Taylor EJ, Robert L, Chmielowski B, Spasic M, Henry G, Ciobanu V, et al. PD-1 blockade induces responses by inhibiting adaptive immune resistance. Nature. 2014:515(7528): 568-71. 
72. Daud Al, Loo K, Pauli ML, Sanchez-Rodriguez R, Sandoval PM, Taravati K, Tsai K, Nosrati A, Nardo L, Alvarado MD, et al. Tumor immune profiling predicts response to anti-PD-1 therapy in human melanoma. J Clin Invest. 2016; 126(9):3447-52.

73. Ngiow SF, Young A, Jacquelot N, Yamazaki T, Enot D, Zitvogel L, Smyth MJ. A threshold level of Intratumor CD8+ T-cell PD1 expression dictates therapeutic response to anti-PD1. Cancer Res. 2015;75(18):3800-11.

74. Gros A, Parkhurst MR, Tran E, Pasetto A, Robbins PF, llyas S, Prickett TD, Gartner JJ, Crystal JS, Roberts IM, et al. Prospective identification of neoantigen-specific lymphocytes in the peripheral blood of melanoma patients. Nat Med. 2016;22(4):433-8.

75. Larkin J, Hodi FS, Wolchok JD. Combined Nivolumab and Ipilimumab or monotherapy in untreated melanoma. N Engl J Med. 2015;373(13):1270-1.

76. Subudhi SK, Aparicio A, Gao J, Zurita AJ, Araujo JC, Logothetis CJ, Tahir SA, Korivi BR, Slack RS, Vence L, et al. Clonal expansion of CD8 T cells in the systemic circulation precedes development of ipilimumab-induced toxicities. Proc Natl Acad Sci U S A. 2016;113(42):11919-24.

77. Tran E, Turcotte S, Gros A, Robbins PF, Lu YC, Dudley ME, Wunderlich JR, Somerville RP, Hogan K, Hinrichs CS, et al. Cancer immunotherapy based on mutation-specific CD4+ T cells in a patient with epithelial cancer. Science (New York, NY). 2014;344(6184):641-5.

78. Yuan J, Ginsberg B, Page D, Li Y, Rasalan T, Gallardo HF, Xu Y, Adams S, Bhardwaj N, Busam K, et al. CTLA-4 blockade increases antigen-specific CD8(+) T cells in prevaccinated patients with melanoma: three cases. Cancer Immunol Immunother. 2011:60(8):1137-46.

79. Ng Tang D, Shen Y, Sun J, Wen S, Wolchok JD, Yuan J, Allison JP, Sharma P. Increased frequency of ICOS+ CD4 T cells as a pharmacodynamic biomarker for anti-CTLA-4 therapy. Cancer Immunol Res. 2013;1(4):229-34.

80. Valzasina B, Piconese S, Guiducci C, Colombo MP. Tumor-induced expansion of regulatory $T$ cells by conversion of CD4+CD25- lymphocytes is thymus and proliferation independent. Cancer Res. 2006;66(8):4488-95.

81. Curti A, Pandolfi S, Valzasina B, Aluigi M, Isidori A, Ferri E, Salvestrini V, Bonanno G, Rutella S, Durelli I, et al. Modulation of tryptophan catabolism by human leukemic cells results in the conversion of CD25- into CD25+ T regulatory cells. Blood. 2007;109(7):2871-7.

82. Wei J, Wu A, Kong LY, Wang Y, Fuller G, Fokt I, Melillo G, Priebe W, Heimberger AB. Hypoxia potentiates glioma-mediated immunosuppression. PLoS One. 2011;6(1):e16195.

83. Hall BM, Pearce NW, Gurley KE, Dorsch SE. Specific unresponsiveness in rats with prolonged cardiac allograft survival after treatment with cyclosporine. III. Further characterization of the CD4+ suppressor cell and its mechanisms of action. J Exp Med. 1990;171(1):141-57.

84. Brimnes MK, Vangsted AJ, Knudsen LM, Gimsing P, Gang AO, Johnsen HE, Svane IM. Increased level of both CD4+FOXP3+ regulatory T cells and CD14 + HLA-DR(-)/low myeloid-derived suppressor cells and decreased level of dendritic cells in patients with multiple myeloma. Scand J Immunol. 2010; 72(6):540-7.

85. Cao X, Cai SF, Fehniger TA, Song J, Collins LI, Piwnica-Worms DR, Ley TJ. Granzyme B and perforin are important for regulatory T cell-mediated suppression of tumor clearance. Immunity. 2007;27(4):635-46.

86. Yuan XL, Chen L, Li MX, Dong P, Xue J, Wang J, Zhang TT, Wang XA, Zhang FM, Ge HL, et al. Elevated expression of Foxp3 in tumor-infiltrating Treg cells suppresses T-cell proliferation and contributes to gastric cancer progression in a COX-2-dependent manner. Clin Immunol (Orlando, Fla). 2010;134(3):277-88.

87. Ghiringhelli F, Menard C, Terme M, Flament C, Taieb J, Chaput N, Puig PE, Novault S, Escudier B, Vivier E, et al. CD4+CD25+ regulatory T cells inhibit natural killer cell functions in a transforming growth factor-beta-dependent manner. J Exp Med. 2005;202(8):1075-85.

88. Larmonier N, Marron M, Zeng Y, Cantrell J, Romanoski A, Sepassi M, Thompson S, Chen X, Andreansky S, Katsanis E. Tumor-derived CD4(+ CD25(+) regulatory $T$ cell suppression of dendritic cell function involves TGF-beta and IL-10. Cancer Immunol Immunother. 2007;56(1):48-59.

89. Ladoire S, Mignot G, Dabakuyo S, Arnould L, Apetoh L, Rebe C, Coudert B, Martin F, Bizollon $\mathrm{MH}$, Vanoli A, et al. In situ immune response after neoadjuvant chemotherapy for breast cancer predicts survival. J Pathol. 2011;224(3):389-400.

90. Salama P, Phillips M, Grieu F, Morris M, Zeps N, Joseph D, Platell C, lacopetta B. Tumor-infiltrating FOXP3+ T regulatory cells show strong prognostic significance in colorectal cancer. J Clin Oncol. 2009;27(2):186-92.
91. Haas M, Dimmler A, Hohenberger W, Grabenbauer GG, Niedobitek G, Distel LV. Stromal regulatory T-cells are associated with a favourable prognosis in gastric cancer of the cardia. BMC Gastroenterol. 2009;9:65.

92. Lowther DE, Goods BA, Lucca LE, Lerner BA, Raddassi K, van Dijk D, Hernandez AL, Duan X, Gunel M, Coric V, et al. PD-1 marks dysfunctional regulatory T cells in malignant gliomas. JCI Insight. 2016;1(5).

93. Hodi FS, Butler M, Oble DA, Seiden MV, Haluska FG, Kruse A, Macrae S, Nelson M, Canning C, Lowy I, et al. Immunologic and clinical effects of antibody blockade of cytotoxic T lymphocyte-associated antigen 4 in previously vaccinated cancer patients. Proc Natl Acad Sci U S A. 2008;105(8): 3005-10.

94. Liakou Cl, Kamat A, Tang DN, Chen H, Sun J, Troncoso P, Logothetis C, Sharma P. CTLA-4 blockade increases IFNgamma-producing CD4+ICOShi cells to shift the ratio of effector to regulatory $T$ cells in cancer patients. Proc Natl Acad Sci U S A. 2008;105(39):14987-92.

95. Romano E, Kusio-Kobialka M, Foukas PG, Baumgaertner P, Meyer C, Ballabeni P, Michielin O, Weide B, Romero P, Speiser DE. Ipilimumab-dependent cellmediated cytotoxicity of regulatory $T$ cells ex vivo by nonclassical monocytes in melanoma patients. Proc Natl Acad Sci U S A. 2015;112(19): 6140-5.

96. Li Z, Dong P, Ren M, Song Y, Qian X, Yang Y, Li S, Zhang X, Liu F. PD-L1 expression is associated with tumor FOXP3(+) regulatory T-cell infiltration of breast Cancer and poor prognosis of patient. J Cancer. 2016;7(7):784-93.

97. Hatziioannou A, Alissafi T, Verginis P. Myeloid-derived suppressor cells and T regulatory cells in tumors: unraveling the dark side of the force. J Leukoc Biol. 2017;102(2):407-21.

98. Rodriguez PC, Zea AH, Culotta KS, Zabaleta J, Ochoa JB, Ochoa AC. Regulation of T cell receptor CD3zeta chain expression by L-arginine. J Biol Chem. 2002;277(24):21123-9.

99. Ellyard JI, Simson L, Parish CR. Th2-mediated anti-tumour immunity: friend or foe? Tissue Antigens. 2007;70(1):1-11.

100. Tarhini AA, Edington H, Butterfield LH, Lin Y, Shuai Y, Tawbi H, Sander C, Yin $Y$, Holtzman M, Johnson J, et al. Immune monitoring of the circulation and the tumor microenvironment in patients with regionally advanced melanoma receiving neoadjuvant ipilimumab. PLoS One. 2014;9(2):e87705.

101. Bjoern J, Juul Nitschke N, Zeeberg Iversen T, Schmidt H, Fode K, Svane IM. Immunological correlates of treatment and response in stage IV malignant melanoma patients treated with Ipilimumab. Oncoimmunology. 2016;5(4): e1100788.

102. Meyer C, Cagnon L, Costa-Nunes CM, Baumgaertner P, Montandon N, Leyvraz L, Michielin O, Romano E, Speiser DE. Frequencies of circulating MDSC correlate with clinical outcome of melanoma patients treated with ipilimumab. Cancer Immunol Immunother. 2014;63(3):247-57.

103. De Henau O, Rausch M, Winkler D, Campesato LF, Liu C, Cymerman DH, Budhu S, Ghosh A, Pink M, Tchaicha J, et al. Overcoming resistance to checkpoint blockade therapy by targeting PI3Kgamma in myeloid cells. Nature. 2016;539(7629):443-7.

104. Couzin-Frankel J. Breakthrough of the year 2013. Cancer immunotherapy. Science (New York, NY). 2013;342(6165):1432-3.

105. Zitvogel L, Galluzzi L, Smyth MJ, Kroemer G. Mechanism of action of conventional and targeted anticancer therapies: reinstating immunosurveillance. Immunity. 2013;39(1):74-88.

106. Smyth EC, Lagergren J, Fitzgerald RC, Lordick F, Shah MA, Lagergren P, Cunningham D. Oesophageal cancer. Nat Rev Dis Primers. 2017:3:17048.

107. Twyman-Saint Victor C, Rech AJ, Maity A, Rengan R, Pauken KE, Stelekati E, Benci JL, Xu B, Dada H, Odorizzi PM, et al. Radiation and dual checkpoint blockade activate non-redundant immune mechanisms in cancer. Nature. 2015;520(7547):373-7.

108. Demaria S, Formenti SC. Radiation as an immunological adjuvant: current evidence on dose and fractionation. Front Oncol. 2012;2:153.

109. Barker HE, Paget JT, Khan AA, Harrington KJ. The tumour microenvironment after radiotherapy: mechanisms of resistance and recurrence. Nat Rev Cancer. 2015;15(7):409-25.

110. Chen DS, Mellman I. Elements of cancer immunity and the cancer-immune set point. Nature. 2017;541(7637):321-30. 